Abstracta Iranicacta Iranica

Revue bibliographique pour le domaine irano-aryen

Volume 40-41 | 2019

Comptes rendus des publications de 2017-2018

\title{
Susan Tyler-Smith. The Coinage Reforms (600-603) of Khusru II and the Revolt of Vistähm
}

\section{Rika Gyselen}

\section{(2) OpenEdition}

1 Journals

\section{Édition électronique}

URL : http://journals.openedition.org/abstractairanica/49676

DOI : 10.4000/abstractairanica.49676

ISBN : 1961-960X

ISSN : 1961-960X

Éditeur :

CNRS (UMR 7528 Mondes iraniens et indiens), Éditions de l'IFRI

Référence électronique

Rika Gyselen, «Susan Tyler-Smith. The Coinage Reforms (600-603) of Khusru II and the Revolt of Vistāhm », Abstracta Iranica [En ligne], Volume 40-41 | 2019, document 30, mis en ligne le 30 octobre 2019, consulté le 20 avril 2021. URL : http://journals.openedition.org/abstractairanica/49676 ; DOI https://doi.org/10.4000/abstractairanica.49676

Ce document a été généré automatiquement le 20 avril 2021.

Tous droits réservés 


\title{
Susan Tyler-Smith. The Coinage Reforms (600-603) of Khusru II and the Revolt of Vistāhm
}

\author{
Rika Gyselen
}

\section{RÉFÉRENCE}

Susan Tyler-Smith. The Coinage Reforms (600-603) of Khusru II and the Revolt of Vistāhm. Londres: Royal Numismatic Society, Special Publication no. 54, 2017, 292 p. ISBN 0-901-405-89-2

1 À la fin des années 1960 sont apparus plusieurs "trésors monétaires" dont la monnaie la plus récente est datée de l'an 12 de Husraw II (d'où sa dénomination 'trésor de l'an 12'). Ils auraient été trouvées à Shiraz ('trésor de Shiraz'). On a estimé le nombre à 37.000 drahm, dont une toute petite partie est parvenue dans les collections de l'Orientalisches Münzkabinett de Jena dont le catalogue, sous forme de sylloge, fait partie de cet ouvrage.

Quelques chapitres sont spécifiquement consacrés au 'trésor de Shiraz' : sa découverte et les publications de quelques autres parties de ce trésor; l'étude de quelques monnaies spécifiques que contient ce trésor et une comparaison avec d'autres trésors monétaires de l'époque sassanide tardive. Si quelques chapitres ont trait à des questions générales comme la réforme monétaire des années de règne 11-13 de Husraw II ou la révolte de Wistāhm dont les dates les plus plausibles seraient 595 à 600, d'autres traitent de questions plus numismatiques comme la typologie des drahm des années 1 à 13 de Husraw II. Deux aspects, incontournables lorsqu'on étudie le monnayage de Husraw II, sont (1) la raison d'être de la légende marginale abd "merveilleux " et (2) l'identification des ateliers monétaires qui frappaient monnaie. L'ouvrage se termine par plusieurs appendices et un index. 
3 À l'exception de coquilles et d'erreurs dans les citations des articles et des ouvrages en français, cet ouvrage est de présentation très soignée et est indispensable pour tous ceux qui s'intéressent à l'histoire un peu mouvementée de la révolte de Wistāhmet à la réforme monétaire qui s'ensuit. Ce livre reflète les connaissances numismatiques actuelles. Les prises de positions de l'auteur bénéficient de sa longue expérience numismatique ce qui mène parfois à remettre en question certaines 'certitudes'.

\section{AUTEURS}

\section{RIKA GYSELEN}

CNRS, Mondes iranien et indien 